\title{
PENDAPATAN JASA BERBASIS SAK PADA RUMAH SAKIT WAHIDIN SUDIROHUSODO MAKASSAR
}

\author{
Eka Ariaty Arfah \\ Dosen Jurusan Akuntansi, STIE Wira Bhakti Makassar \\ e-mail: ekhasweet82@yahoo.co.id
}

\begin{abstract}
ABSTRAK
Rumah sakit adalah merupakan salah satu organisasi nirlaba. Salah satu hal yang sangat penting dalam penyajian informasi akuntansi pada organisasi nirlaba, dalam hal ini rumah sakit adalah mengenai masalah pengukuran jumlah, saat dan kepastian aliran pendapatan. Tujuan penelitian ini adalah untuk mengetahui apakah Rumah Sakit Wahidin Sudirohusodo di Makassar telah sesuai dengan Standar Akuntansi Keuangan pada tahun 2015 sampai 2016.

Penelitian ini menggunakan penelitian kualitatif dengan pendekatan deskriptif komparatif dan melakukan observasi dan perhitungan terhadap datadata yang tercatat dalam laporan aktivitas dan laporan arus kas. Metode analisis data yang digunakan dalam penelitian ini adalah PSAK No. 45 dan PSAK No.23 bahwa pengakuan pendapatan secara khusus telah memiliki Standar yaitu pernyataan Standar akuntansi keuangan No.23 dan PSAK no 45.

Hasil Penelitian ini menunjukkan bahwa laporan keuangan pada Rumah Sakit Wahidin Sudirohusodo di Makassar sudah sesuai dengan Standar Akuntansi Keuangan (SAK) hal ini dapat dilihat dari Rumah Sakit Wahidin Sudirohusodo dalam prakteknya bahwa sudah menerapkan sistem akuntansi dalam rangka pelaporan keuangan. Laporan keuangan terlampir menyajikan secara wajar, dalam seтиa hal yang material, posisi keuangan BLU-RSUP Dr. Wahidin Sudirohusodo Makassar tanggal 31 Desember 2016, serta kinerja keuangan dan arus kas untuk tahun yang berakhir pada tanggal tersebut, sesuai dengan Standar Akuntansi Keuangan.
\end{abstract}

Kata Kunci : Pengakuan, Pendapatan, Keuangan, SAK, Rumah Sakit

\section{PENDAHULUAN}

Rumah sakit merupakan salah satu organisasi nirlaba. Organisasi nirlaba berbeda dengan organisasi bisnis, perbedaan utama yang mendasar terletak pada cara organisasi memperoleh sumber daya yang dibutuhkan untuk melakukan berbagai aktivitas operasinya. Organisasi nirlaba memperoleh sumber daya dari sumbangan para anggota dan para penyumbang lain yang tidak mengharapkan imbalan apapun dari organisasi tersebut.

Sebagai akibat dari karateristik tersebut, dalam organisasi nirlaba timbul transaksi tertentu yang jarang atau bahkan tidak pernah terjadi dalam organisasi bisnis,misalnya penerimaan sumbangan. Namun demikian dalam praktik organisasi nirlaba sering tampil dalam berbagai bentuk sehingga seringkali sulit dibedakan dengan organisasi bisnis pada umumnya. Pada beberapa bentuk organisasi nirlaba, meskipun tidak ada kepemilian, organisasi tersebut mendanai kebutuhan modalnya dari utang dan kebutuhan oprasinya dari pendapatan atas jasa yang diberikan kepada publik. Akibatnya, pengukuran jumlah,saat, dan 
kepastian aliran pemasukan kas menjadi ukuran kinerja penting bagi para pengguna laporan keuangan organisasi tersebut, seperti kreditur dan pemasok dana lainnya.

Para pengguna laporan keuangan organisasi nirlaba memiliki kepentingan bersama yang tidak berbeda dengan organisasi bisnis, yaitu untuk menilai : 1) Jasa yang diberikan oleh organoisasi nirlaba dan kemampuannya untuk terus memberikan jasa; 2) Cara manajer melaksanakan tanggungjawabnya dan aspek kinerja manajer.

Kemampuan organisasi untuk terus memberikan jasa dikomunikasikan melalui laporan posisi keuangan yang menyediakan informasi mengenai aktiva, kewajiban, aktiva bersih, dan informasi mengenai hubungan diantara unsur-unsur tersebut. Laporan ini harus menyajiakan secara terpisah aktiva bersih baik yang terikat maupun yang tidak terikat penggunaannya.

Agar para pemakai laporan keuangan terutama pihak luar (ekstern) tidak memberikan penafsiran yang keliru, maka laporan keuangan yang dihasilkan diharuskan menggunakan cara, metode dan prosedur tertentu untuk menghasikan informasi yang lengkap, objektif, relevan, jujur dan dapat diperbandingkan sehingga dapat memenuhi kebutuhan serta dapat diterima oleh semua pihak yang berkepentingan. Untuk memenuhi tujuan tersebut diperlukan suatu pedoman pelaksana, pengumpulan dan pengelolahan data akuntansi yang diterima dan dipahami oleh semua pihak yang berkepentingan dan dapat diterapkan dalam praktekdan penyusunan laporan keuangan sesuai dengan ketentuan dan standar akuntansi yang diterima umum, di Indonesia dikenal dengan Standar Akuntansi Keuangan (SAK).

Salah satu hal yang sangat penting dalam penyajian informasi akuntansi pada organisasi nirlaba, dalam hal ini rumah sakit adalah mengenai masalah pengukuran jumlah, saat dan kepastian aliran pendapatan. Menurut PSAK No.23 (2010), pendapatan sehubungan dengan transaksi penjualan jasa harus diakui dengan acuan pada tingkat penyelesaian dari transaksi pada tanggal neraca. Pengakuan pendapatan dengan acuan ini sering disebut sebagai metode presentase penyelesaian.

Berdasarkan peraturan Menteri Keuangan No. 76/PMK 05/2008 tentang pedoman akuntansi dan pelaporan keuangan Badan Layanan Umum pasal 6 ayat 2 dan 4 menyatakan bahwa sistem akuntansi keuangan BLU menghasilkan laporan keuangan sesuai dengan SAK/Standar Akuntansi Industri spesifik Badan Layan Umm (BLU) dan dalam rangka pengintegrasian Laporan Keuangan Badan Layanan Umum (BLU) dengan Laporan Keuangan Kementrian Negara/Lembaga, Badab Layanan Umum BLU mengembangkan subsistem akuntansi keuangan yang menghasilkan laporan keuangan sesuai dengan SAP. Dalam pasal 17 ayat 3 menyatakan bahwa BLU yang tidak memenuhi ketentuan sebagai dimaksud dalam ayat (2) dan (4) dapat dikenakan sangsi tariff fleksibelitas BLU, remunerasi,dan status BLU.

Berdasarkan latar belakang yang telah dikemukakan, maka yang menjadi permasalahan pokok yang dibahas dalam penulisan ini adalah apakah pengakuan pendapatan jasa Rumah Sakit Wahidin Sudirohosodo Di Makassar telah sesuai dengan Standar Akuntansi Keuangan. Dan tujuan penelitian adalah untuk 
mengetahui metode pengakuan pendapatan pada Rumah Sakit Wahidin Sudirohosodo Di Makassar sedangkan manfaat penelitian adalah untuk menambah wawasan dan pengetahuan dalam memberikan sumbangan pemikiran pada Rumah Sakit Wahidin Sudirohosodo Di Makassar mengenai cara pengakuan pendapatan yang sesuai dengan Standar Akuntansi Keuangan (SAK).

\section{Pendapatan}

Rumah sakit merupakan salah satu organisasi nirlaba yang usaha pokoknya memberikan jasa pelayanan dalam bidang kesehatan. Rumah sakit memperoleh sumberdaya dari sumbangan para anggota dan para penyubang lain. Oleh karna itu pengukuran jumlah, saat dan kepastian aliran pendapatan menjadi ukuran kinerja penting dalam laporan keuangannya.

Pernyataan dalam PSAK 45 bertujuan untuk mengatur pelaporan keuangan organisasi nirlaba. Dengan adanya standar pelaporan, diharapkan laporan keuangan organisasi nirlaba dapat lebih mudah dipahami, memiliki relevansi, dan memiliki daya banding yang tinggi (Pontoh, 2012).

Pendapatan dapat ditemui dalam berbagai literatur akuntansi baik mengenai sumber, cara memperoleh maupun cara mengukurnya. Pedapatan ini dapat terjadi setiap saat dan dapat pula terjadi pada waktu-waktu tertentu. Harnanto (2002) menjelaskan bahwa pendapatan meliputi sumber-sumber ekonomi yang diterima oleh perusahaan dari transaksi penjualan barang dan penyerahan jasa kepada pihak lain. Menurut Accounting Terminology Bulletin No.2 yang dikemukan oleh Deddi (2009) pendapatan didefinisikan sebagai penjualan barang dan penyerahan jasa, serta diukur dengan pembebanan yang dikenakan kepada pelanggan, klien, atau penyewa untuk barang jasa yang disediakan bagi mereka. SFAC No. 6 mendefinisikan pendapatan merupakan pemasukan atau peningkatan aktiva suatu perusahaan atau penyelesaian kewajiban perusahaan atau campuran keduanya selama satu periode tertentu akibat penyerahan atau pembuatan suatu produk, pelayanan jasa, atau kegiatan lain yang merupakan kegiatan utama perusahaan yang berkesinambungan (Santoso, 2010).

Pengakuan pendapatan dalam Standar Akuntansi Keuangan PSAK No. 23 revisi 2010 (2010) dikatakan bahwa pendapatan harus diukur dengan nilai wajar imbalan yang diterima atau dapat diterima. Menurut Rudianto (2010) Pengakuan Pendapatan adalah waktu (timing) di akuinya pendapatan oleh rumah sakit. Dari beberapa definisi serta penjelasan yang dikemukakan oleh berbagai ahli yang telah diuraikan di atas mengenai pengertian revenue sudah cukup jelas, baik mengenai sumbernya maupun cara pengukurannya. Untuk itu penulis dapat menarik beberapa kesimpulan sehubungan dengan revenue sebagai berikut :

a. Pendapatan (revenue) bias terjadi setiap saat, dan bias juga terjadi secara berkala atau pada saat tertentu.

b. Pendapatan (revenue) diperoleh melalui hasil penjualan barang atau jasa, dengan kata lain revenue timbul karna adanya barang atau jasa yang dijual kepada konsumen. Pendapatan dapat pula diperoleh dari penjualan atau pertukaran aktiva diluar barang atau pertukaran aktiva tetap juga dari hasil investasi seperti bunga, deviden dan lain-lain. 
c. Pendapatan (revenue) yang sifatnya menambah atau menaikkan nilai kekayaan pemilik akibat adanya penilaian kembali atas aktiva tetap perusahaan dan aktiva yang timbul dari pembelian harta, investasi oleh pemilik, pinjamanpinjaman ataupun koreksi rugi laba periode tahun lalu, tidak dapat dikategorikan sebagai pendapatan (rеvenue).

\section{Penghasilan}

Pengertian penghasilan (income) sering disamakan dengan pengertian pendapatan (revenue), padahal dalam literatur akuntansi sesungguhnya kedua istilah tersebut mempunyai arti yang berbeda. Jika pendapatan masih merupakan pendapatan kotor yang belum dikurangi biaya dan beban untuk memperolehnya, maka penghasilan adalah pendapatan dikurangi dengan biaya (cost) dan beban (expense).

Untuk mengetahui lebih lanjut tentang pengertian penghasilan maka penulis mengutip beberapa definisi yang dikemukakan oleh para ahli dalam berbagai literatur akuntansi. Baridwan (2002) memberikan definisi penghasilan sebagai berikut : penghasilan (income) adalah penghasilan-penghasilan sesudah dikurangi biaya-biaya, bila pendapatan lebih kecil dari biaya, selisihnya sering disebut rugi. Dalam hal ini yang dimaksud dengan penghasilan adalah penerimaan-penerimaan bersih yang diperoleh dari hasil penjualan barang dagangan atau jasa selama satu periode dikurangi dengan biaya-biaya yang terjadi dalam periode dimana hasil itu diperoleh (periode yang sama).

Pengakuan penghasilan dalam Ikatan Akuntansi Indonesia (IAI) PSAK No. 23 (2010) penghasilan didefinisikan sebagai peningkatan manfaat ekonomi selama periode akuntansi dalam bentuk arus masuk atau peningkatan asset atau penurunan leabilitas yang mengakibatkan kenaikan ekuitas, yang tidak berasal dari kontribusi penanaman modal.

Penghasilan (income) meliputi baik pendapatan (revenue) maupun keuntungan (gains). Pendapatan timbul dalam pelaksanaan aktivitas perusahaan yang biasa dan dikenal dengan sebutan yang berbeda seperti penjualan, penghasilan jasa (fees), bunga, deviden, royalti dan sewa.

Dari sejumlah definisi mengenai pendapatan dan income yang telah dikemukakan diatas, maka jelaslah bahwa income tidak sama dengan revenue, walaupun dalam arti sehari-hari sering kita mendengar bahwa kedua istilah tersebut adalah sama padahal keduanya adalah berbeda walaupun mempunyai kaitan yang erat satu sama lainnya.

\section{Saat pengakuan pendapatan}

Menurut Standar Akuntansi Keuangan (2010) memberikan penjelasan bahwa penghasilan diakui dalam laporan laba rugi kalau kenaikan manfaat ekonomi dimasa depan yang berkaitan dengan peningkatan aktiva atau penurunan kewajiban telah terjadi dan dapat diukur dengan andal. Ini berarti pengakuan penghasilan terjadi bersamaan dengan pengakuan kenaikan aktiva atau penurunan kewajiban (misalnya, kenaikan bersih aktiva yang timbul dari penjualan barang atau penurunan kewajiban yang timbul dari pembebasan pinjaman yang masih harus dibayar. 
Selanjutnya penjelasan tentang saat diakuinya pendapatan yang dikemukakan dalam PSAK No. 12 (2010) mengenai asumsi dasar akuntansi (konsep dasar akuntansi) mengemukakan salah satu diantaranya mengenai pengakuan pendapatan bahwa pengukuran aktiva, kewajiban,pendapatan,beban serta perubahannya diakui pada saat terjadi, tidak pada saat diterima atau dibayarkan, dicatat dan berpengaruh pada laporan keuangan pada periode kejadian.

Dari beberapa penjelasan mengenai saat penentuan pendapatan yang dikutip penulis dari berbagai literatur akuntansi, pada dasarnya sama yaitu bahwa pendapatan diakui :

a. Saat penjualan.

b. Saat selesainya produksi

c. Secara proposional selama tahap produksi

d. Saat pembayaran diterima

\section{Pengukuran Pendapatan}

Harahap (2011) menyatakan bahwa pengukuran adalah proses penetapan jumlah uang untuk mengakui dan memasukkan setiap unsur laporan keuangan dalam neraca atau laporan laba rugi. Riahi, et al (2006) menyatakan bahwa pengukuran memiliki arti pemberian angka-angka kepada objek atau kejadiankejadian menurut aturan-aturan tertentu. Hendriksen (2000) bahawa pendapatan paling baik diukur dengan nilai pertukaran produk atau jasa perusahaan. Menurut Belkoui (2006) pengukuran memiliki arti "pemberian angka-angka kepada objek atau kejadian-kejadian menurut aturan tertentu. Nilai pertukaran ini menyatakan ekuivalen kas atau nilai sekarang yang didiskontokan dari klaim uang yang akhirnya akan diterima dari transaksi pendapatan. Keuntungan diperlakukan serupa dengan pendapatan kecuali bahwa biaya yang berhubungan segera diofsetkan untuk memperoleh keuntungan bersih. Dalam penjualan aktiva yang tidak biasa diperdagangkan oleh perusahaan, biaya-biaya ini mencakup nilai aktiva yang dijual ditambah biaya langsung penjualan.

\section{Pengakuan Pendapatan Rumah Sakit}

Pendapatan (revenue) dalam organisasi nirlaba, termasuk didalamnya rumah sakit merupakan salah satu hal yang berbeda secara signifikan dibandingkan dengan pendapatan pada perusahaan atau bisnis komersial. Pada rumah sakit pendapatan diperoleh dari berbagai sumber. Akan tetapi derajat akan kebebasan penggunaannya berbeda tergantung jenis pendapatannya. Tergantung pada batas yang diberikan oleh sumber pendapatan tadi. Pada perusahaan komersial pendapatan diperoleh dari kegiatan atau penjualan produknya. Penggunaan pendapatan tergantung pada kebijakan manajemen sendiri.

PSAK Nomor 45 menggolongkan berbagai macam pendapatan organisasi nirlaba kedalam dua golongan besar yaitu pendapatan bersumber dari sumbangan dan pendapatan nonsumbangan. Tergolong dalam pendapatan yang masuk dalam kategori sumbangan adalah semua penerimaan yang didapat oleh yayasan, dimana yayasan tidak perlu menghasilkan atau menyajiakan sesuatu jasa atau barang pada pemberinya. Sumbangan diharapkan akan "dibayar" oleh yayasan dalam bentuk 
jasa atau produk yang dihasilkan dari program-program yang didesain oleh yayasan.

Selain sumbangan, organisasi nirlaba dapat memperoleh sumbangan pendapatan lain dari usaha sendiri. Pengertian usaha sendiri yayasan adalah bentuk pendapatan yang diperoleh dari siapa saja dan dari sumbangan mana saja sesudah yayasan memberikan suatu balas jasa langsung kepada pemberinya.

\section{Cara Penyajian Pendapatan Dalam Laporan Keuangan}

Laporan keuangan organisasi nirlaba meliputi laporan posisi keuangan pada ahir periode laporan, laporan aktivitas serta laporan arus kas untuk suatu periode pelaporan dan catatan atas laporan keuangan. Posisi pendapatan berada pada laporan aktivitas, dimana tujuan utama dari laporan aktivitas ini adalah menyediakan informasi mengenai:

a. Pengaruh transaksi dan peristiwa lain yang mengubah jumlah dan sifat aktiva bersih.

b. Hubungan antara transaksi dan peristiwa lain

c. Bagaimana penggunaan sumber daya dalam pelaksanaan berbagai program atau jasa.

Laporan aktivitas menyajikan pendapatan sebagai penambahan aktiva bersih tidak terikat, kecuali jika penggunaanya dibatasi oleh penyumbang, dan menyajikan beban sebagai pengurang aktiva bersih tidak terikat. Sumbangan disajikan sebagai penambah aktiva bersih tidak teriat, terikat permanent,atau terikat temporer tergantung ada tidaknya pembatasan.

Laporan aktivitas menyajikan jumlah pendapatan secara bruto. Namun demikian pendapatan investasi dapat disajikan secara netto dengan syarat bebanbeban terkait seperti penitipan dan beban penasihat investasi diuangkapkan dalam catatan atas laporan keuangan.

\section{METODE PENELITIAN}

\section{Lokasi dan Waktu Penelitian}

Objek penelitian dilakukan di Rumah Sakit Wahidin Sudirohusodo di Makassar yang berlokasi di Jl. Perintis Kemerdekaan Km. 11 Tamalanrea Makassar. Waktu yang diperlukan dalam penelitian ini adalah kurang lebih dua bulan yaitu mulai Januari sampai Februari 2016 .

\section{Sumber Data}

Adapun sumber data yang akan digunakan dalam penulisan ini adalah sebagai berikut :

1. Data primer yaitu data yang diperoleh melalui wawancara dan pengamatan langsung ke Rumah sakit.

2. Data sekunder yaitu semua data informasi tertulis lainnya yang berhubungan dengan penulisan ini yaitu laporan keuangan Rumah Sakit Wahidin Sudirohusodo.

\section{Metode pengumpulan data}

Dalam hal ini pengumpulan data dilakukan dengan menggunakan metode sebagai berikut : 


\section{Observasi}

Yaitu dilakukan dengan mengadakan pengamatan langsung pada Rumah Sakit Wahidin Sudirohusodo di Makassar untuk mendapatkan data-data yang relevan dalam penelitian ini.

\section{Interview/wawancara}

Yaitu dilakukan dengan cara mengadakan wawancara langsung dengan pihakpihak yang terkait untuk mendapatkan informasi yang akurat.

\section{Metode Analisis Data}

Sesuai dengan tujuan penelitian, maka dalam membahas permasalahan yang ada, digunakan metode deskriptif komperatif, yaitu dengan membandingkan pengakuan dan pelaporan pendapatan dalam rumah sakit dengan standar akuntansi keuangan (SAK).

Pengakuan pendapatan secara khusus telah mempunyai standar, yaitu pernyataan Standar Akuntansi Keuangan nomor 23 mengenai pendapatan. Dalam pengakuan pendapatan yang disusun IAI dalam PARS mengacu pada standar keuangan yang berhubungan, yaiu PSAK No 23 tentang pendapatan. Selain PSAK No 23 PARS juga menekankan pelaksanaan PSAK No 1 yang intinya adalah rumah sakit mengakui pendapatan dengan basis akrual.

PSAK No.45 Tentang Pelaporan Keuangan Organisasi Nirlaba. Peraturan Mentri Keuangan Nomor 76/PMK.05/2008 tentang Pedoman Akuntansi dan Pelaporan Keuangan Badan Layanan Umum. Peraturan Pemerintah (PP) No.74 Tahun 2012 tentang Pengelolahan Keuangan Badan Layanan Umum.

\section{HASIL PENELITIAN}

Tabel 1

Laporan Aktivitas Tahun 2016 - 2015

\begin{tabular}{|c|l|r|r|r|}
\hline No & \multicolumn{1}{|c|}{ Uraian } & \multicolumn{1}{c|}{ Selisih } & \multicolumn{1}{c|}{ Tahun 2016 } & \multicolumn{1}{c|}{ Tahun 2015 } \\
\hline 1 & Pendapatan operasional rawat jalan & 149.670 .439 .674 & 285.519 .439 .678 & 135.849 .000 .000 \\
\hline 2 & Pendapatan operasional rawat inap & 29.970 .522 .665 & 269.136 .584 .860 & 239.166 .062 .195 \\
& Sub Jumlah Pendapatan Operasional & 179.640 .962 .339 & $\mathbf{5 5 4 . 6 5 6 . 0 2 4 . 5 3 8}$ & $\mathbf{3 7 5 . 0 1 5 . 0 6 2 . 1 9 9}$ \\
\hline 3 & Hibah/donasi/sumbangan non pemerintah & 1.657 .744 .394 & 5.107 .491 .928 & 3.449 .747 .534 \\
\hline 4 & Pendapatan APBN & -21.358 .406 .543 & 88.261 .472 .869 & 109.619 .879 .412 \\
& -Operasional & -7.224 .275 .176 & 40.798 .768 .785 & 48.023 .043 .961 \\
& -Investasi & -28.582 .681 .719 & $\mathbf{1 2 9 . 0 6 0 . 2 4 1 . 6 5 4}$ & $\mathbf{1 5 7 . 6 4 2 . 9 2 3 . 3 7 3}$ \\
& Sub Jumlah Pendapatan APBN & 2.759 .781 .400 & 17.105 .873 .413 & 14.346 .092 .013 \\
\hline 5 & Pendapatan usaha lainnya & 155.475 .806 .414 & $\mathbf{7 0 5 . 9 2 9 . 6 3 1 . 5 3 3}$ & $\mathbf{5 5 0 . 4 5 3 . 8 2 5 . 1 1 5}$ \\
\hline & Jumlah Pendapatan & & & \\
\hline
\end{tabular}


Tabel 2

Laporan Arus Kas

\begin{tabular}{|l|r|r|}
\hline \multicolumn{1}{|c|}{ URAIAN } & \multicolumn{1}{|c|}{$\mathbf{2 0 1 6}$} & \multicolumn{1}{|c|}{$\mathbf{2 0 1 5}$} \\
\hline A. Arus Kas Dari Aktivitas Operasi & & \\
Arus Kas Masuk & 554.656 .024 .538 & 375.015 .062 .199 \\
1. Pendapatan usaha dari jasa layanan & 5.107 .491 .928 & 3.449 .747 .534 \\
2. Pendapatan hibah & 129.060 .241 .654 & 157.642 .923 .373 \\
3. Pendapatan APBN (Rupiah Murni) & 17.105 .873 .413 & 14.346 .092 .013 \\
4. Pendapatan usaha lainnya & - & \\
5. Pendapatan transfer dana Jamkesmas dari Pusat & - & - \\
6. Penerimaan lainnya & $\mathbf{7 0 5 . 9 2 9 . 6 3 1 . 5 3 3}$ & $\mathbf{5 5 0 . 4 5 3 . 8 2 5 . 1 1 9}$ \\
Jumlah Arus Masuk & & \\
B. Arus Kas Dari Aktivitas Investasi & \\
Arus Kas Masuk & & \\
1. Hasil penjualan asset tetap & & \\
2. Hasil penjualan investasi jangka panjang & \\
3. Hasil penjualan asset lainnya & \\
Jumlah Arus Masuk & & \\
C. Arus Kas Dari Aktivitas Pendanaan Arus Masuk & \\
1. Perolehan pinjaman & & \\
2. Penerimaan kembali pokok pinjaman & & \\
Jumlah Arus Masuk & & \\
\hline
\end{tabular}

\section{PEMBAHASAN}

\section{Konsep Pengakuan Pendapatan Rumah Sakit Berdasarkan SAK}

Dalam Standar Akuntansi Keuangan, pendapatan Rumah Sakit diperoleh dari berbagai sumber. Dalam PSAK No. 45 menggolongkan berbagai macam pendapatan Rumah Sakit kedalam dua golongan besar yaitu pendapatan bersumber dari sumbangan dan pendapatan non sumbangan.

Pendapatan sumbangan diperoleh dari:

1. Pemerintah (bantuan social, bantuan dana program dll)

2. Badan-badan usaha (perusahaan-perusahaan)

3. Donor Lokal atau lembaga nirlaba penyalur sumbangan.

4. Donor internasional.

5. Masyarakat (sumbangan lewat mass media, donasi tetap setiap bulan, dll)

Dalam rangka pencatatan pendapatan pada rumah sakit, manajemen harus menentukan titik mana pendapatan diakui karna pemilihan titik pengakuan pendapatan akan berimplikasi terhadap besarnya pendapatan yang dilaporkan dalam laporan aktivitas dalam suatu periode. Laporan keuangan organisasi nirlaba meliputi laporan posisi keuangan ada ahir periode laporan, laporan aktivitas serta laporan arus kas untuk suatu periode pelaporan dana catatan atas laporan keuangan.posisi pendapatan berada pada laporan aktivitas.

Pengakuan pendapatan secara khusus telah mempunyai standar, yaitu pernyataan Standar Akuntansi Keuangan nomor 23 mengenai pendapatan. Dalam pengakuan pendapatan yang disusun IAI dalam Peraturan Akuntansi Rumah Sakit (PARS) mengacu pada standar keuangan yang berhubungan, yaiu PSAK No 23 tentang pendapatan. Selain PSAK No 23 PARS juga menekankan pelaksanaan PSAK No 1 yang intinya adalah rumah sakit mengakui pendapatan dengan basis akrual. 
Pengakuan pendapatan merurut SAK didasarkan pada akrual yaitu pengakuan beban maupun pendapatan pada saat terjadinya dan bukan pada saat kas atau setrata kas diterima atau dibayarkan (kas basis). Sehingga pada saat penyerahan barang atau pada saat transaksi penjualan berlangsung merupakan saat diakuinya pendapatan dan beban secara bersamaan (matching principle).

Untuk lebih jelasnya, penulis mengutip beberapa transaksi yang terjadi sehubungan penjualan jasa pada Rumah Sakit Wahidin Sudirohusodo.

1. Tanggal 26 Desember 2016 dicatat jumlah pasien rawat inap sebanyak 17 orang kelas III, 6 orang kelas II, 7 orang kelas I, 4 orang di VIP.

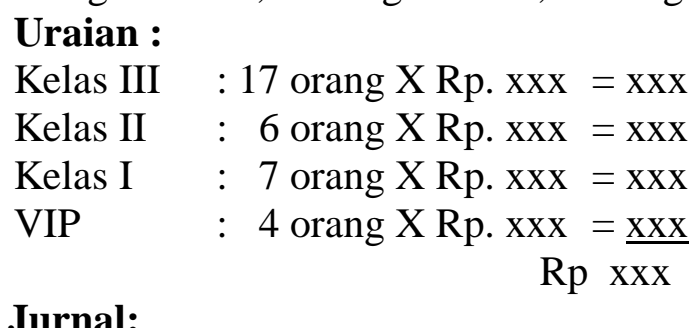

Jurnal:

Piutang Rp. xxx

Pendapatan rawat inap Rp. $x x x$

2. Pada tanggal 30 Desember 2016 dua orang pasien rawat inap, pada tanggal 26 Desember 2016 dikelas I telah keluar dari rumah sakit.

Jurnal:

Kas Rp. $x x x$

Piutang

Ket : 2 orang $x 5$ hari $x$ Rp. $x x x=R p . x x x$ Rp. $x x x$

\section{Konsep Pengakuan Pendapatan Rumah Sakit Wahidin Sudirohusodo.}

Rumah Sakit Wahidin Sudirohusodo merupakan salah satu rumah sakit milik pemerintah. Oleh karna itu, sumber utama keuangannya berasal dari sumbangan pemerintah. Sumbangan yang diperoleh kemudian digunakan oleh rumah sakit dalam kegiatan operasionalnya memberikan pelayanan kesehatan kepada masyarakat.

Berdasarkan penelitian yang telah dilakukan, Rumah Sakit Wahidin Sudirohusodo dalam pelaksanaan kegiatan oprasionalnya melakukan pencatatan penerimaan setiap hari. Kemudian pada ahir bulan bagian pendapatan akan membuat laporan pendapatan bulanan. Pendapatan diakui pada saat terjadi pemberian jasa. Metode pengakuan pendapatan yang digunakan adalah presentase penyelesaian, dimana pendapatan diakui sesuai dengan besarnya jasa yang telah disesuaikan.

\section{a. Proses Pencatatan Pendapatan Rawat Inap}

Bagi pasien rawat inap sebelum keruang opname, pasien ke sentral opname untuk menentukan jenis ruang (kelas) opname yang akan digunakan.

Kelas III (bangsal) :Rp. xxx /hari

Kelas II : Rp. $\mathrm{xxx} /$ hari

Kelas I : Rp. xxx/hari

Ket. Diluar tindakan (inap + pemeriksaan dokter) 


\section{Jurnal :}

Pada saat pasien dirawat :

Untuk kelas III yaitu:

Piutang Rp. xxx
Pendaptan rawat inap Rp. $x x x$

Untuk kelas II

Piutang Rp. $x x x$

Pendapatan rawat inap Rp. $x x x$

Untuk kelas I

Piutang Rp. xxx

Pendapatan rawat inap Rp. $\mathrm{xxx}$

\section{b. Saat Pengakuan Pendapatan Loket Rawat Inap}

Pendapatan diakui setelah terjadinya pemberian jasa. Metode pengakuan pendapatan yang digunakan adalah accrual basis dimana pendapatan diakui sesuai dengan besarnya jasa yang telah disesuaikan.

Bagi pasien yang menggunakan ASKES tidak dikenakan biaya pendaftaran maupun biaya tindakan, kecuali yang tidak termasuk tanggungan rumah sakit seperti jenis obat-obatan tertentu, maka pasien menebus obat yang tidak di tanggung ASKES.

Rumah sakit Wahidin Sudirohusodo dalam prakteknya sudah menerapkan sistem akuntansi dalam rangka pelaporan keuangan. Laporan keuangan terlampir menyajikan secara wajar, dalam semua hal yang material, posisi keuangan Badan Layanan Umum-Rumah Sakit Umum Pusat (BLURSUP) Dr. Wahidin Sudiro-husodo tanggal 31 Desember 2016, serta kinerja keuangan dan arus kas untuk tahun yang berahir pada tanggal tersebut, sesuai dengan Standar Akuntansi Keuangan.

\section{c. Pengakuan pendapatan dan beban}

1. Pengakuan usaha dari jasa layanan (rawat inap, rawat jalan, rawat darurat) diakui pada saat pelayanan selesai diberikan atau hak untuk menagih yang timbul sehubungan dengan adanya barang / jasa yang diserahkan kepada masyarakat.

2. Pendapatan hibah diakui pada saat hak kepemilikan barang berpindah ke Badan Layanan Umum Rumah Sakit Wahidin Sudirohusodo (BLU RSWS )atau pada saat kas atau uang diterima oleh Badan Layanan Umum Rumah Sakit Wahidin Sudirohusodo (BLU RSWS)

3. Pendapatan dari APBN diakui pada saat pengeluaran belanja dipertanggung jawabkan dengan diterbitkannya Surat Pemerintah Pencarian Dana (SP2D) dan dicatat sebesar nilai pengeluaran bruto belanja pada SPM.

4. Beban diakui pada saat timbulnya beban tersebut sebesar jumlah yang digunakan untuk pelayanan RS, jumlah yang telah dibayar, jumlah yang 
harus dibayarkan, jumlah yang diestimasi atau sebesar jumlah yang dialokasikan.

\section{d. Pendapatan Yang Diperoleh Dari Sumbangan.}

1. Pemerintah (bantuan sosial, bantuan dana program dan lain-lain)

2. Bahan-bahan usaha (perusahaan-perusahaan)

3. Donor lokal atau lembaga nirlaba penyalur sumbangan

4. Donor internasional

5. Masyarakat (sumbangan lewat mas media, donasi,tetap setiap bulan,dan lain-lain).

\section{e. Saat Pengakuan Pendapatan Loket Poliklinik.}

Pada poliklinik pendapatan diakui pada saat pasien melakukan pembayaran sebelum adanya pemeriksaan terhadappasien tersebut. Sehingga menurut SAK pendaptan loket poliklinik didasarkan pada standar kas basis yaitu pada saat kas diterima atau di bayarkan.

\section{PENUTUP}

Kesimpulam

1. Penerimaan pendapatan dari kegiatan oprasional rumah sakit dicatat setiap hari kemudian pada ahir bulan disusun dalam laporan pendapatan bulanan.

2. Proses pencatatan pendapatan poliklinik, pencatatan pendapatan rawat inap, dan pencatatan pendapatan lain-lain pada Rumah Sakit Wahidin Sudirohusodo telah digunakan penjurnalan yang sesuai dengan SAK.

3. Pendapatan diakui dengan menggunakan metode akrual basis, dimana pendapatan diakui pada saat penyelesaian pemberian jasa. Metode pencatatanya adalah kas basis yaitu pencatatan pendapatan dilakukan bersamaan dengan penerimaan uang (kas).

Rumah sakit wahidin sudirohusodo dalam prakteknya sudah menerapkan sistem akuntansi dalam rangka pelaporan keuangan. Laporan keuangan terlampir menyajikan secara wajar, dalam semua hal yang material, posisi keuangan Badan Layanan Umum-Rumah Sakit Umum Pusat (BLU-RSUP) Dr. Wahidin Sudiro-husodo Makassar tanggal 31 Desember 2016, serta kinerja keuangan dan arus kas untuk tahun yang berahir pada tanggal tersebut, sesuai dengan Standar Akuntansi Keuangan.

4. Dari uraian diatas dapat disimpulkan bahwa pengakuan pendapatan Rumah Sakit Wahidin Sudirohusodo sudah sesuai dengan Standar Akuntansi Keuangan.

\section{Saran}

1. Agar tetap dapat memberikan laporan yang relevan dan sesuai dengan Standar Akuntansi Keuangan (SAK), maka bagi pihak-pihak yang berkepentingan hendaknya tetap menerapkan sistem akuntansi dalam pelaporannya untuk dapat menjadikan Rumah Sakit Wahidin Sudirohusodo yang berstandar internasional. 
2. Untuk mencerminkan pendapatan yang diterima pada suatu periode tahun baku, maka harus menggunakan Standar Akuntansi Keuangan untuk mendapatkan dan mencatat pendapatan yang sebenarnya yang sesuai dengan SAK.

\section{DAFTAR PUSTAKA}

Baridwan dan Zaki. 2002. Intermediate Accounting. Edisi 7. Penerbit Fakultas Ekonomi Universitas Gajah mada, Yogyakarta.

Bastian, 1. 2010. Akuntansi Sektor Publik. Jakarta: Erlangga.

Belkoui, Ahmed Riahi 2006, Accounting Theory, Teori Akuntansi, Edisi Kelima, Salemba Empat, Jakarta.

Deddi Nordiawan. 2009. Akuntansi Pemerintahan, Salemba Empat Jakarta

Harnanto. 2002. Akuntansi Keuangan Intermediate. Edisi 2. Cetakan 1. Yogyakarta.

Harnanto. 2002. Akuntansi Keuangan Menengah. Buku BPFE.

Yogyakarta.Harahap, Sofyan Syafri. 2011. Teori Akuntansi. Edisi Revisi 2011. Rada Grafindo Persada. Jakarta.

Ikatan Akuntan Indonesia 2007, Standar Akuntansi Keuangan, Salemba Empat, Jakarta.

Ikatan Akuntan Indonesia, 2010. Pernyataan Standar Akuntansi Keuangan, (PSAK) No.23.

Pontoh, C. (2012). Penerapan PSAK No. 45 pada Gereja Bukit Zaitun Luwuk. Jurnal EMBA Vol 1No. 13, hal123-139.

Riahi, Ahmed., Belkaoui. 2006. Accounting Theory, Teori Akuntansi. Edisi Lima. Salemba Empat. Jakarta.

Santoso, Imam. 2010. Akuntansi Keuangan Menengah (Intermediate Accounting). Buku Satu. Refika Aditama. Bandung. 